International Journal of Instruction e-ISSN: 1308-1470 • www.e-iji.net
July $2020 \bullet$ Vol.13, No.3

p-ISSN: 1694-609X

pp. 329-342

Received: 17/06/2019

Revision: 21/01/2020

Accepted: 26/01/2020

OnlineFirst:23/04/2020

\title{
Effectiveness of CEL-Badis Learning Model on Students' Creative- Thinking Skills: Case on the Topic of Simple Food Biotechnology
}

\section{Idam Ragil Widianto Atmojo}

Dr., Faculty of Teacher Training and Education, Universitas Sebelas Maret, Indonesia, idamragil@fkip.uns.ac.id

\section{Sajidan}

Prof., Faculty of Teacher Training and Education, Universitas Sebelas Maret, Indonesia, sajidan@fkip.uns.ac.id

This research aimed to determine the effectiveness of Creative Entrepreneurship Learning Based on Discovery Skills (CEL-BaDiS) in improving students' creativethinking skills on the simple food biotechnology topic. This research is a quasiexperiment using the pretest-posttest control-group design in a state university in Surakarta, Indonesia in the 2018/2019 academic year with one class as an experimental class using the CEL-BaDiS model and the other class as the existing class using a Project-Based Learning (PjBL) model. The data were obtained using an essay test instrument to measure creative-thinking skills through expert validations, namely validation from the education and evaluation expert, biotechnology expert, and certified science lecturer, as well as an empirical validation through trials. The results demonstrated that the average score of the score gain calculation of creative-thinking skills in the experimental class was higher by 0.65 compared to that of the existing class of 0.52 . The independent sample t-test shows the difference between the experimental class and the existing class with the $t$ value of 2.1491. Based on the findings, it can be summed up that creative-thinking skills in flexibility, fluency, originality, and elaboration aspects can be improved effectively through the activities of the CEL-BaDiS model.

Keywords: creative-thinking skill, biotechnology, creative learning, learning, students

\section{INTRODUCTION}

In the $21^{\text {st }}$ century, all humans will face many global challenges that they need to prepare themselves to have the skills to deal with developments in the disruption and globalization era (Thompson \& Miller, 2017; Musa, Mufti, Latiff, \& Amin, 2012). There are a number of competencies and skills that need to be possessed in the $21^{\text {st }}$ century; they are critical-thinking and problem-solving skills, communication and

Citation: Atmojo, I. R. W., \& Sajidan (2020). Effectiveness of CEL-Badis Learning Model on Students' Creative-Thinking Skills: Case on The Topic of Simple Food Biotechnology. International Journal of Instruction, 13(3), 329-342. https://doi.org/10.29333/iji.2020.13323a 
collaboration skills, information and communication technology literacy skills, contextual learning skills, creative and innovative skills, and information and media literacy skills (Choi, Lee, Shin, Kim, \& Krajcik, 2011;Wrahatnolo \& Munoto, 2018). In the 21 st century, education has become increasingly essential to ensure students have life and career skills, learning and innovation skills, information, media and technology skills (Putri, Risdianto, \& Sutarno, 2017). This variety of skills can be empowered to students during the learning process and become the main learning objective (İnel \& Balım, 2013).

Simple food biotechnology is important to improve because it increases the quality of food, converts and improves nutrition from food ingredients for the better and is more beneficial with the help of microorganisms. At present, the application of biotechnology is not only in microorganisms, but also in plants and animals. There are 4 basic principles of biotechnology, namely the use of biological agents, using certain methods, the production of a derivative product, and involving many scientific disciplines. According to its development, general biotechnology is divided into two types, namely Conventional (simple) and Modern Biotechnology. This research focuses on conventional biotechnology in the food sector. Conventional Biotechnology is biotechnology that utilizes organisms directly to produce goods and services that are beneficial to humans through the fermentation process. Conventional biotechnology is usually done simply and not produced in large quantities. In the food sector, fermentation is a microbial activity on foodstuffs to produce the desired product. In the field of food, the process that is assisted by microorganisms, for example by fermentation, can produce yogurt, cheese, tempeh, bread, soy sauce, vinegar, and donuts.

Educational experts in Indonesia have formulated the Indonesian Qualification Framework (IQF) for tertiary institutions (undergraduates are at level 6 above diploma 3 and below the professional level) as a new standard for producing quality graduates in accordance with the demands of society, especially in the $21^{\text {st }}$ century working world and skills (Wrahatnolo \& Munoto, 2018). The preparation of IQF has been adapted to qualifications from other countries, which will provide wider mobility and create recognition of international equality in the competencies and skills of Indonesian creative graduates so as to facilitate student and labour exchanges.

Creative-thinking skills are individual skills to think about what everyone has thought and done, so that he/she is able to do things that have not been done and thought by others. Creative thinking is one of the skills needed in the $21^{\text {st }}$ century, especially in overcoming social problems, namely high unemployment due to low creative-thinking skills (Rahardjanto, Husamah, \& Fauzi, 2019). The core of creative thinking is in innovation that helps to do old things using new ways. Creative thinking is one's ability to create new ideas or thoughts that make him/her feel capable of achieving his/her various goals in life (I. R.W. Atmojo, Sajidan, Sunarno, \& Ashadi, 2019).

Students who have creative-thinking skills will try to think complex. Therefore, the skills need to be accustomed to being empowered and trained in learning so that they become the provision for pre-service elementary school teachers to face the future 
through the implementation of learning models that can facilitate creative-thinking skills.

The low creative-thinking skills were found in the national and international education. The low creative-thinking skills at the national level were found in many parts of Indonesia, as evidenced by the research results of (Zubaidah, Fuad, Mahanal, \& Suarsini, 2017) in Malang and Wulandari, Widayati, \& Suryobroto(2016) in Bogor. The research conducted by (Hidayat, Susilaningsih, \& Kurniawan, 2018) at Vocational High School Raja PermaisuriBainun, Ipoh, Malaysia, (Turkey, 2018) in Jordan, and (Somintara, Sukkamart, \& Pimdee, 2018) in Thailand also showed that students' thinking skills in some countries of the world still need to be improved.

According to PISA (Program for International Students Assessment), the science performance of Indonesian students ranked $60^{\text {th }}$ out of 65 participating countries in 2009, $64^{\text {th }}$ of 65 participating countries in 2012 , and $69^{\text {th }}$ of 75 participating countries in 2015 (OECD, 2010; 2014; 2016). These findings indicate that the Indonesian students' highorder thinking skills need to be empowered and trained so that the result of each test conducted by PISA can increase, which, in general, is still below the average score (OECD) (Suprapto, 2016).

In fact, the creative-thinking skills pre-service elementary school teachers at universities in Surakarta, Indonesia, are still low. Based on the results of the research that has been done about the profile of creative-thinking skills of students in Surakarta, out of 115 students, only $12 \%$ (14 students) are included in the creative category and the rest still need guidance and motivation (Suryandari, Sajidan, Rahardjo, Prasetyo, \& Fatimah, 2018). This can be seen from the symptoms of problems that dominate the observation results during the lecture process of biotechnology in the classroom; they include: (1) divergent-thinking patterns were not used shown by a small number of alternative answers; (2) the students had difficulty making high-order thinking skill questions and answers (C4-C6); (3) some students are passive when doing group work; (4) the students have not been able to provide various interpretations of an image, a story, or a problem; (5) some of them had difficulty giving consideration to situations (problems) different from those given by others; and (6) they have not been able to think of problems or things that others have never thought of.

The observation results were then supported by the initial profile test results containing four aspects of creative-thinking skills in accordance with the indicators of Torrance, E. P. (1990), namely fluency, flexibility, elaboration, and originality on 120 fourthsemester students. Of the four indicators, only two were in the good category (fluency of $37 \%$ and flexibility of $35 \%$ ). The other two indicators, elaboration and originality, were still lacking by $28 \%$ and $15 \%$, respectively (Atmojo, Idam Ragil Widianto, Sajidan, Widha Sunarno, 2017). Therefore, it can be concluded that low creative-thinking skills are still a real problem that occurs in the elementary school teacher education study program in Surakarta Indonesia.

The students' low creative-thinking skills are a problem to be solved (Astutik, S., \& Prahani, B. K., 2018; Rahardjanto, A., Husamah, H., \& Fauzi, A. 2019). Various efforts 
are required to improve the skills because they have an important role in life. When creative-thinking skills are owned, students can think fluently, flexibly, elaborately, and originally (Torence, E. P. 1990). Creative-thinking skills can be empowered and trained in various ways. Some research results using learning models can improve creativethinking skills, such as the research result of (Rahardjanto et al., 2019) on the use Hybrid-PjBL to improve pre-service teachers' creative thinking. Creative-thinking skills can also be empowered through Field Trip Overseas activities according to (Suacamram, 2018). According to (Astutik \& Prahani, 2018), the use of PhET in science learning applications integrated with CCL in the form of simulations also turned out to improve student creativity. One of the most widely chosen and used methods to solve problems related to creative-thinking skills for fourth-semester students in Surakarta Indonesia in the biotechnology topic is to use learning models because they are easier to implement in classroom learning (Husamah et al., 2018).

$\mathrm{PjBL}$ learning model is a learning model that can facilitate science learning (Musa, Mufti, Latiff, \& Amin, 2012). PjBL model is also the right model for training students' creative-thinking skills (Pucher \& Lehner, 2011). The learning model implemented to empower students' creative-thinking skills is a model that is able to stimulate the $21^{\text {st }}$ century thinking skills. The model used is Creativity Entrepreneurship Based on Discovery Skill (CEL-BaDiS) model. CEL-BaDiS model is an innovative learning model developed based on discovery skills according to (Dyer, Gregerse, \& Christensen, 2011), which was developed based on literature reviews and learning theories that underlie the way to teach and empower students' creative-thinking skills. This model can be used to train the aspects of students' creative-thinking skills through six syntactic activities in the model; they are association, questioning, analysing, creating, communicating, and persuasion networking entrepreneurship (Pratama R. R, 2019).

The interview results with students and lecturers demonstrated that the applied science material that would be useful later for the fourth-semester students at universities in Surakarta Indonesia was the biotechnology topic. This is due to the characteristics of the biotechnology topic, which is close to everyday life consisting of red, green, blue, and white biotechnology (Atmojo. IRW, Sajidan, Sunarno, Ashadi, \& Nugraha, 2018) and simple biotechnology. Complex biotechnology sub-topics make it difficult for students to understand. In addition, they also have to produce products from the concepts learned. This is also reinforced from the average result of the performance test on the product produced and the final semester test over the past two years which shows that the average mastery is still in the low category. Based on the description of the background above, this research aimed to examine whether the application of the Creative Entrepreneurship Learning Based on Discovery Skill (CEL-BaDiS) model is effective in improving creative-thinking skills, especially on the biotechnology topic. 


\section{METHOD}

\section{Research Design}

This research is a quasi-experimental research with the pretest-posttest control-group design (Creswell, 2012). It applies the Creative Entrepreneurship Learning Based on Discovery Skill (CEL-BaDiS) model in the experimental class while the inquiry learning model, commonly implemented by lecturers at universities, is applied to the existing class. Each class was pretested before being given treatment before the posttest was carried out. Scores were given on the results of the pretest and posttest in accordance with the assessment rubric. The data were then statistically analysed. The data were analysed with SPSS 22.0 for Windows to find out the results of the pretest-posttest descriptive analysis, one sample Kolmogorov-Smirnov normality test, Lavene's homogeneity test, N-gain calculation with Hake interpretation (1999), and Independent Sample t-test. On one hand, the effect-size test was performed using the interpretation of Glass (1976), Hedges (1981), and Cohen (1988).

\section{Population and Sample}

The research population were the students of elementary school teacher education study programs in Surakarta. The samples were 62 fourth-semester students of the 2018/2019 academic year. Sampling was done purposively at the university based on the analysis results of the final semester test and the creative-thinking skill test in the initial profile. 31 students in the experimental class were taught using CEL-BaDiS model while those in the existing class were taught using the commonly-used learning model by lecturers on campus.

\section{Research Instruments}

The creative-thinking skill data were taken using an essay-test instrument created based on 4 indicators of creative thinking according to Torrence (1990), namely flexibility, fluency, elaboration, and originality. Each aspect of creative-thinking skills is developed, each of which results in 3 indicators, so, overall, there are 12 indicators. One example of the indicators of the fluency aspect is putting forward many ways to solve problems, of the flexibility aspect is providing various ways to solve problems, of the originality aspect is modifying something that already exists, and of the elaboration aspect is testing the problem with detailed procedures. All these indicators have been modified with the indicators of entrepreneurship. The instrument used was validated by some experts (certified education and evaluation expert, biotechnology expert, and biology lecturer) and empirically validated using experimental tests showing that the instrument used was valid and reliable. The essay questions used have an interval score of 1-4 in accordance with the criteria of each. The instrument validity test was performed using the Pearson Product Moment correlation test with the following conditions: if $r>r_{\text {table }}$, the item is valid and if $r<r_{\text {table }}$, the item is declared invalid and not used. The validity test instrument obtained the lowest score of 0.3380 and the highest of $0.6396>f_{\text {table }}$ with 20 students as respondents with the rv value of 0.443 , meaning that the instrument items of creative-thinking skills are valid. The reliability test using 
Cronbach's Alpha obtained $0.790>0.443$, meaning that each item is reliable to be implemented in the experimental and existing classes.

\section{FINDINGS}

\section{Descriptive Analysis Results of Pretest and Posttest Gain Scores of Creative- Thinking Skills}

The descriptive analysis results of the pretest and posttest of creative-thinking skills in the experimental class are presented in Table 1 as follows.

Table 1

Descriptive Analysis Results of Pretest and Posttest Scores

\begin{tabular}{cllllll}
\hline Test Types & Classes & Number of Students & Min Score & Max Score & Mean & Std \\
\hline \multirow{2}{*}{ Pretest } & Existing & 31 & 54 & 70 & 61.55 & 4.82 \\
& Experimental & 31 & 55 & 72 & 63.65 & 5.24 \\
Posttest & Existing & 31 & 65 & 79 & 72.55 & 5.28 \\
& Experimental & 31 & 70 & 88 & 81 & 6.33 \\
\hline
\end{tabular}

Table 1 shows the results of the descriptive analysis of creative-thinking skills before and after the treatment is given to the experimental and existing classes. The test results show that between the experimental and existing classes, the average score of the pretest is not much different of 61.55 and 63.65. It does not differ much from the average score of the pretest indicating that the classes used in this research have the same ability. Meanwhile, the average posttest score in the experimental and existing classes shows a considerable difference, that is, the average score of the posttest in the experimental class is 81 greater than that of the existing class of 72.55 .

\section{Gain-Score Analysis of Pretest and Posttest Scores of Creative-Thinking Skills}

The pretest and posttest scores of the creative-thinking skill were then calculated to determine the level of improvement of the results of the CEL-BaDiS model on the biotechnology topic. The summary of the results of the average score analysis of the results of the creative-thinking skill test is presented in Table 2 below.

Table 2

TGain-Score Analysis Results of Pretest and Posttest Scores of Creative-Thinking Skills

\begin{tabular}{lll}
\hline Classes & Mean of Gain Score & Criteria \\
\hline Existing & 0.50 & Medium \\
\hline Experimental & 0.65 & Medium \\
\hline
\end{tabular}

Table 2 shows that the average gain scores in the experimental class of 0.65 in the medium category and in the existing class of 0.50 in the moderate category, according to Hake (1999). The average gain score of the experimental class is higher than that of the existing class.

\section{Independent Sample t-Test Analysis Result}

An independent sample t-test was performed to find out the difference between the $\mathrm{N}$ gain score of creative-thinking skills in the existing and the experimental classes. The 
prerequisite tests, normality and homogeneity tests, were carried out before the t-test, which show that the average score of the pretest and posttest of creative-thinking skills in the experimental and existing classes is normally distributed but not homogeneous. Therefore, the advanced test using independent sample t-test can be done by reading the calculation result in the column of equal variances not assumed. The independent sample t-test results can be seen in Table 3 below.

Table 3

The Independent Sample T-Test Results

\begin{tabular}{llll}
\hline \multirow{2}{*}{ Data } & \multicolumn{2}{l}{ t-test for equality of means } \\
\cline { 2 - 4 } & $\mathrm{T}$ & Df & Sig. (2-tailed) \\
\hline Equal variances not assumed & 2.1491 & 54.923 & 0.001 \\
\hline
\end{tabular}

The independent sample t-test result shows that the sig. ( 2 tailed) value is $0.001<0.05$, then $\mathrm{H}_{0}$ is rejected and $\mathrm{H}_{\mathrm{a}}$ is accepted. Thus, there is a difference of the average $\mathrm{N}$-gain score between the experimental and existing classes. This difference shows that CELBaDiS model applied to the experimental class is effective in improving the students' creative-thinking skills. The level of effectiveness of the model in enhancing creativethinking skills can be figured out by the advanced test after the independent sample ttest and effect-size test.

\section{Effect-Size Test Analysis Result}

The results of the effect-size test analysis using the Cohen test for independent sample $t$ test, Hedges's g and Glass's with the Rstat Effect Size Calculator for the t-test on the Ngain score are shown in Table 4 below.

Table 4

The Analysis Results of the Effect-Size Test

\begin{tabular}{lllll}
\hline Types & Cohen & Hedges & Glass & Interpretation \\
\hline Existing & 0.417 & 0.412 & 0.436 & Medium \\
Experimental & 1.450 & 1.432 & 1.600 & Large \\
\hline
\end{tabular}

The results of the effect-size analysis show that the use of CEL-BaDiS model in learning has a big effect on the empowerment of creative-thinking skills as indicated by the effect-size test results based on the formulas of Cohen 1.450, Hadges 1.432, and Glass 1.600 .

\section{DISCUSSION}

Creative Entrepreneurship Learning Based Discovery Skill (CEL-BaDiS) model implemented on the biotechnology topic has the potential to improve creative-thinking skills as indicated by the independent sample t-test and the effect-size test. Creative Entrepreneurship Learning is a combination of Creative thinking and entrepreneurship skills indicators including innovative, market-minded, risk-taking and confidence. the indicators are packaged into six stages of learning which include association, questioning, analysing, creating, communication, and persuasion, and networking entrepreneurship (I. R.W. Atmojo et al., 2019). The result of the independent sample ttest shows that the sig. ( 2 tailed) value is $0.001<0.05$, then $\mathrm{H}_{0}$ is rejected and $\mathrm{H}_{\mathrm{a}}$ is 
accepted. Thus, there is a difference in the $\mathrm{N}$-gain average scores between the existing and experimental classes. This difference shows that the learning model applied to the experimental class is effective in empowering students' creative-thinking skills. The effectiveness of CEL-BaDiS model in empowering creative-thinking skills from the effect-size test analysis with the Rstat Effect Size Calculator for t-Test on N-gain scores shows that the use of the model in learning has a big effect on creative-thinking skills, as shown by the effect-size test results based on the formula of Cohen's d 1.450, Hedges's 1.432, and Glass's 1.600. This effect shows that there is a big effect from the application of the learning model on the aspects of students' creative-thinking skills.

The results of this effect-size are the impacts of the treatment given to the variables to be developed (Sullivan \&Feinn, 2012). The treatment is the result of the syntactic activity of the CEL-BaDiS model based on some researches of learning theories that train students' thinking skills. CEL-BaDiS learning model trains the aspects of students' creative-thinking skills through six syntaxes, which include association, questioning, analysing, creating, communication, and persuasion, and networking entrepreneurship (I. R.W. Atmojo et al., 2019). The research result is relevant to the one conducted by (Srikoon, Bunterm, Nethanomsak, \& Tang, 2018) that creative thinking can be improved through 5P model, (Wang, 2019) using the creative problem-solving model to improve learner creativity in the English class, and (Songkram \& Puthaseranee, 2015) using the E-learning system model in a virtual learning environment to enhance creative thinking in college.

The association syntax in CEL-BaDiS model on the biotechnology topic in empowering aspects of creative-thinking skills in elaboration aspects. The empowerment of the elaboration aspect through the association syntax is based on activities in this stage, which can facilitate it. The association syntax becomes the first stage of activities in the learning model developed which starts with the associating stage, the first step taken by students to start looking for ideas relevant with the material being studied. The idea search was done by exploring articles through the internet that will stimulate creativity, especially the elaboration skill. The elaboration aspect includes skills in developing ideas facilitated by analysing at least 6 scientific articles from research results consisting of 2 domestic scientific articles and 4 overseas research articles. The articles analysed were the articles about the results of biotechnology researches used as references for making a new product (examples of fermented food: yougurt that comes from horse milk, tape that comes from kepok bananas, dragon fruit donuts and many more). The fermented food is a modification and development of the existing food based on the information from the associated article. From the articles analysed, students can develop their ideas to make a new or the modified existing product. At this association stage, it can also empower the originality aspect because here students can produce new ideas and thoughts as a result of modifying some of the research results being analysed. Meanwhile, there is support based on the learning theory in the knowledge association stage and on the syntax of the CEL-BaDiS model because Bloom's thinking taxonomy in the form of categories allows students to implement high-order thinking skills, one of which is the creative-thinking skill (Anderson \&Krathwohl, 2001). At the end of the activity at this initial stage, students can produce an initial draft plan (idea) to make a 
product from the simple biotechnology, which is a fermented product which will later be used for the next CEL-BaDiS stage.

The second syntax is questioning on the biotechnology topic effective in training the aspects of creative-thinking skills in the fluency and originality aspects. The fluency aspect in creative thinking is a skill in thinking fluently to produce several ideas and provide various alternative solutions to problems. The originality aspect is the ability to produce ideas to create truly new products or ideas for making the modified products or ideas to replace the existing ones. Both aspects are facilitated by the questioning syntax. The activity in the questioning syntax is the product blueprint of the ideas produced from the association stage. Then, the design was made using the flipchart paper and the Power Point slides were made for the product plan visualization to visualize the idea of fermented products that will be used in the questioning stage. Questioning activities were carried out using the gallery walk method. The gallery walk is a cooperative learning method in which group members are divided into 2 (half of the members are gallery keepers, the others are the visitors) (Chin, Khor, \& Teh, 2015). This gallery walk activity can be done inside or outside the class depending on the number of groups and the size of the class used. Gallery keepers are in charge of explaining, describing, answering questions, and accepting suggestions from every visitor. When explaining and describing the details of the product plan to be made, gallery keepers used flipchart papers and Power Point presented using mobile phones. The explanations include the superiority of the product to be made, its novelty, nutrient content, and how to make it. Visitors are in charge of visiting all the galleries in turn and giving questions and suggestions regarding the products described by the gallery keepers. The gallery walk activity can empower the fluency and originality aspects. The questioning activity facilitates the fluency and originality aspects. When there was an interaction between the gallery keeper and his/her visitor, they asked and answered each other questions, advised, and criticized. This interaction process about the new products that will be created in the questioning syntax can stimulate current thinking skills to generate questions and answers and skills to provide alternative problems to produce new products (Chin et al., 2015). This is in accordance with the opinion stating that the trained questioning skill will develop one's high-order thinking skill, curiosity competencies, creativity, critical-thinking skills, and character as a lifelong learner (Tofade, et al., 2013; Yang, et al. , 2005). The questioning syntax stimulates to create scientific questions, suggestions and explanations focused on the product to be made. The questioning syntax in CEL-BaDiS model can maximize association syntax because the students are required to analyse scientific articles in advance to ask high-order thinking skill questions, so they need to do analysis first before asking. The questioning syntax also builds a social system between the lecturer and students and among fellow students in classroom learning (Cudic, Burt, Santana, \& Principe, 2018).

The analysing syntax is the third stage in CEL-BaDiS model. This stage can empower creative-thinking skills in the elaboration aspect. The activity at this stage is a continuation of the questioning stage which has produced a plan for the fixed fermented new product as a result of inputs and suggestions from the students and other groups. To find out whether the products have already been on the market or available, the students 
analysed traditional markets, supermarkets, and on-line shops. This is called market analysis. This learning activity aimed to finalize the product that would be made to be different from the existing product on the market. It was found that the activities at the analysing stage can improve students' skills to develop ideas and break them down to be more detailed and interesting (Hayashi, Ogawa, \& Nakano, 2013). The final result in the analysing stage is a product plan that has been finalized and is ready to be made at a later stage.

The next syntax is creating or the product manufacturing process. At this stage, the originality aspect of creative-thinking skills was empowered. At this stage, the simple biotechnology product was made, for example the fermented product that had been planned and finalized at the analysing stage. The creating process was carried out in a science laboratory on campus guided by the lecturer and 2 teaching assistants. The process of making a new product requires high creative-thinking skills so that the activities at this stage are able to empower the ability to produce new products and create new ideas and thoughts by making modifications through a unique manufacturing process to produce new biotechnology products (Falloon, 2019). The final result of the creating syntax is a new product resulting from a simple biotechnology process, for example fermentation that has passed the creating stage according to the final result of the association, questioning, and analysing stages.

The next syntax of the CEL-BaDiS model is communicating. At this stage, the students communicated the products produced at the creating stage with their friends in the campus environment. They explained the materials used, how to make the product, and the content of the product written on a poster of 50x50 cm. The poster was used as a medium to make it easier for "buyers" to know information about the products made and product loaders to explain their media information to others. This activity was carried out using the gallery walk method (Chin et al., 2015). The stages of the gallery walk were: (1) Each group made an interesting and informative cardboard poster so that readers can find out the content about the product made; (2) Each group attached the poster in their group and presented it; (3) Each group divided the group members' tasks as a seller and buyers; (4) Each seller had the task of explaining the product he/she made to the buyer through the poster and product made, while the buyer was in charge of giving inputs and suggestions on the products made by other groups, focusing on the taste, packaging, nutrition, how to make it, and the price; and (5) The buyer gave advice by going around to each group until returning to the group and exchanged roles with his/her friends in the group. The results of the communicating stage are inputs or suggestions from other groups about the products that have been made that are marketed on a small scale (limited). Thus, each group can improve its product made to be marketed on a large scale. The communicating stage is a way to express opinions or information to the recipient to inform opinions verbally, behaviourally, or indirectly using the media. In communicating activities, it is necessary to think about how to communicate properly so that the message delivered is understood by others (Chin et al., 2015). 
The final stage of the CEL-BaDiS learning model was Persuasion and Networking Entrepreneurship (PNE) or networking with persuasion. The activities carried out in the product marketing (distribution) phase are in the form of offering directly to prospective buyers using persuasion principles by communicating the superiority of the products made. The PNE stage can be done by marketing through blogs, Facebook, Youtube, online shops, and Instagram by displaying product images and using communicative and informative language so that readers want to buy products made. The products that have entered the PNE stage are expected to be ready-to-use products because they have already gone through the communication, input, advice, and revision stages. The purpose of the use of social media in marketing the products made by the students is that students will have the ability to persuade buyers directly in verbal and writing, using images, colours, and layouts. The results of the PNE stage are fermented food products that have been marketed by the students in various ways. Inputs and advices from buyers are for the improvement of the product. A group is successful if there are people who buy or order its products and give positive testimonials to the food products they made. Based on the description of learning activities in the communicating and PNE stages, these stages can empower creative-thinking skills with the flexibility aspect because students are stimulated that they are able to think flexibly by using various approaches in new ways and solving problems in different ways (Baek \& Falk, 2018).

\section{CONCLUSION}

Based on the results of the research, it can be summed up that the Creative Entrepreneurship Learning Based on Discovery Skills (CEL-BaDiS) learning model applied to the topic of simple biotechnology can improve students' creative-thinking skills. The six stages of CELL-based learning model association, questioning, analysing, creating, communication, and persuasion and networking entrepreneurship can develop students' creative-thinking.. Therefore, each aspect of creative-thinking skills, fluency, flexibility, elaboration, and originality, can be effectively improved through the CELBaDiS model activities. This research is only conducted on pre-service elementary school teachers in the fifth semester, so it needs to be implemented on other research subjects. The research on the implementation of the CEL-BaDiS model can also be carried out to determine differences in creative-thinking skills between men or women, based on different geographic or GPA. In addition to conducting a quasi-experimental research type, the implementation of the CEL-BaDiS model can also be done through a classroom action research and on elementary to high school students. This research implies that the application of the CEL-BaDiS Model to project-oriented learning followed up by selling products made by the students can train them for entrepreneurship. Entrepreneurship is a competency that a teacher must have in addition to professional, pedagogical, social and personality competencies. In addition, it is expected that young people who have entrepreneurial skills can create jobs vacancies to reduce unemployment. This learning model is also an alternative learning model in supporting 21 st century learning because it can enhance creative-thinking skills that are part of High Order Thinking Skills (HOTs) that need to be empowered from primary to tertiary education. 


\section{REFERENCES}

Aiken, L. R. (1980). Content validity and reliability of single items or questionnaires. Educational and Psychological Measurement, 40, 955-959.

Aiken, L. R. (1985). Three coefficients for analyzing the reliability, and validity of ratings. Educational and Psychological Measurement, 45, 131-142.

Anderson, L. W., \& Krathwohl, D.R. (2001). A taxonomy for learning, teacing, and assessing: a revision of Bloom's taxonomy of educational of objectives. New York: Addison Wesley

Astutik, S., \& Prahani, B. K. (2018). The practicality and effectiveness of collaborative creativity learning (CCL) model by using PhET simulation to increase students' scientific creativity. International Journal of Instruction, 11(4), 409-424. https://doi.org/10.12973/iji.2018.11426a.

Atmojo, I., Sajidan, P., Sunarno, W., \& Ashadi, M. (2017). Profile of elementary school pre-service teacher based on high order thinking skills (HOTS) on natural science subject. International Conference on Teacher Training and Education 2017 (ICTTE 2017) Profile, 158(Icecsd), 185-189.

Atmojo, I. R.W., Sajidan, S., Sunarno, W., \& Ashadi, A. (2019). The implementation of skill of disruptive innovators to improve creativity through science learning on green biotechnology conceptions. Journal of Physics: Conference Series, 1157(2). https://doi.org/10.1088/1742-6596/1157/2/022004.

Atmojo, I. R. W., Sajidan, S., Sunarno, W., Ashadi, \& Nugraha, D. A. (2018). The profiles of pre-service elementary teachers (PETs) in biotechnology using RCB. AIP Conference Proceedings, 020063. https://doi.org/10.1063/1.5054467

Baek, E. C., \& Falk, E. B. (2018). Persuasion and influence: what makes a successful persuader? Current Opinion in Psychology, 24, 53-57. https://doi.org/10.1016/j.copsyc.2018.05.004.

Chin, C. K., Khor, K. H., \& Teh, T. K. (2015). Is gallery walk an effective teaching and learning strategy for biology? In E. G. S. Daniel (Ed.), Biology education and research in a changing planet (pp. 55-60). Springer. https://doi.org/10.1007/978-981-287-524-2.

Choi, K., Lee, H., Shin, N., Kim, S. W., \& Krajcik, J. (2011). Re-conceptualization of scientific literacy in South Korea for the 21st century. Journal of Research in Science Teaching, 48(6), 670-697. https://doi.org/10.1002/tea.20424.

Cudic, M., Burt, R., Santana, E., \& Principe, J. C. (2018). A flexible testing environment for visual question answering with performance evaluation. Neurocomputing, 291, 128-135. https://doi.org/10.1016/j.neucom.2018.02.065.

Dyer, J., Gregerse, H., \& Christensen, C. M. (2011). The Innovator DNA Mastering The Five Skill of Distruptive Innovators. Retrieved from http://covwc.com/clientimages/48008/newsletters/covwc_newsletter_july_2016.pdf 
Falloon, G. (2019). Using simulations to teach young students science concepts: An Experiential Learning theoretical analysis. Computers and Education, 135, 138-159. https://doi.org/10.1016/j.compedu.2019.03.001.

Hayashi, Y., Ogawa, Y., \& Nakano, Y. I. (2013). Visualization system for analyzing collaborative learning interaction. Procedia Computer Science, 22, 1379-1387. https://doi.org/10.1016/j.procs.2013.09.227.

Hidayat, T., Susilaningsih, E., \& Kurniawan, C. (2018). The effectiveness of enrichment test instruments design to measure students' creative thinking skills and problemsolving. Thinking Skills and Creativity, 29, 161-169. https://doi.org/10.1016/j.tsc.2018.02.011.

İnel, D., \& Balım, A. G. (2013). Concept cartoons assisted problem based learning method in science and technology teaching and students' views. Procedia - Social and Behavioral Sciences, 93, 376-380. https://doi.org/10.1016/j.sbspro.2013.09.206.

Musa, F., Mufti, N., Latiff, R. A., \& Amin, M. M. (2012a). Project-based learning (PjBL): inculcating soft skills in 21 st century workplace. Procedia -Social and Behavioral Sciences, 59, 565-573. https://doi.org/10.1016/j.sbspro.2012.09.315.

Musa, F., Mufti, N., Latiff, R. A., \& Amin, M. M. (2012b). Project-based Learning (PjBL): Inculcating Soft Skills in 21st Century Workplace. Procedia - Social and Behavioral Sciences, 59(2006), 565-573. https://doi.org/10.1016/j.sbspro.2012.09.315.

Pratama, R. R. (2019). Implementasi Model Pembelajaran Creative Entrepreneurship Learning Based Discovery Skills Untuk Meningkatkan Keterampilan Berpikir Kreatif Pada Pembelajaran IPA Materi Energi Peserta Didik Kelas IV SD. Didaktika Dwija Indria, 7(Nomor 5), 2019.

Pucher, R., \& Lehner, M. (2011). Project based learning in computer science - A review of more than 500 projects. Procedia - Social and Behavioral Sciences, 29, 1561-1566. https://doi.org/10.1016/j.sbspro.2011.11.398.

Putri, D. H., Risdianto, E., \& Sutarno, S. (2017). Pre-Service physics teachers' perception toward hands-on lab activity and 21 st century skills pre- service physics teachers' perception toward hands-on lab activity and 21 st century skills. Journal of Physics: Conference Series, 895, 1-8. https://doi.org/10.1088/1742-6596/895/1/012015.

Rahardjanto, A., Husamah, H., \& Fauzi, A. (2019). Hybrid-PjBL: Learning outcomes, creative thinking skills, and learning motivation of preservice teacher. International Journal of Instruction, 12(2), 179-192. https://doi.org/10.29333/iji.2019.12212a.

Somintara, P., Sukkamart, A., \& Pimdee, P. (2018). Strengthening thai 7th grade student creative thinking skills: A curriculum development model. Asia-Pacific Social Science Review, 18(2), 152-163.

Songkram, N., \& Puthaseranee, B. (2015). E-learning system in virtual learning environment to enhance cognitive skills for learners in higher education. Procedia - Soc and Behavioral Sciences, 174, 776-782. https://doi.org/10.1016/j.sbspro.2015.01.614. 
Srikoon, S., Bunterm, T., Nethanomsak, T., \& Tang, K. N. (2018). Effect of 5P model on academic achievement, creative thinking, and research characteristics. Kasetsart Journal of Social Sciences, 39(3), 488-495. https://doi.org/10.1016/j.kjss.2018.06.011.

Suacamram, M. (2018). Developing creativity and entrepreneurship of undergraduate students through a field trip overseas. International Journal of Instruction, 12(1), 591606. https://doi.org/10.29333/iji.2019.12138a.

Suryandari, K. C., Sajidan, Rahardjo, S. B., Prasetyo, Z. K., \& Fatimah, S. (2018). Project-based science learning and pre-service teachers' science literacy skill and creative thinking. Cakrawala Pendidikan, TH.XXXVII(3), 345-355.

Thompson, S. A., \& Miller, K. L. (2017). Disruptive trends in higher education: Leadership skills for successful leaders. Journal of Professional Nursing, 1-5. https://doi.org/10.1016/j.profnurs.2017.11.008.

Turkey, J. (2018). The level of creative thinking skills among gifted and ordinary students in tafila governorate. Journal of Studies in Education, 8(1), 68. https://doi.org/10.5296/jse.v8i1.12098.

Wang, H. chun. (2019). Fostering learner creativity in the English L2 classroom: Application of the creative problem-solving model. Thinking Skills and Creativity, 31(November 2018), 58-69. https://doi.org/10.1016/j.tsc.2018.11.005.

Wrahatnolo, T., \& Munoto. (2018a). 21st centuries skill implication on educational system. IOP Conference Series: Materials Science and Engineering, 296, 012036. https://doi.org/10.1088/1757-899X/296/1/012036.

Wrahatnolo, T., \& Munoto. (2018b). 21st Centuries skill implication on educational system. IOP Conference Series Materials Science and Engineering, 296, 012036. https://doi.org/10.1088/1757-899X/296/1/012036.

Wulandari, N. H., Widayati, K. A., \& Suryobroto, B. (2016). Cognitive style and creative quality: Influence on academic achievement of university students in Indonesia. HAYATI J of Biosciences, 23(3), 121-124. https://doi.org/10.1016/j.hjb.2016.09.001.

Zubaidah, S., Fuad, N. M., Mahanal, S., \& Suarsini, E. (2017). Improving creative thinking skills of students through Differentiated Science Inquiry integrated with mind map. J of Turkish Sci Edu, 14(4), 77-91. https://doi.org/10.12973/tused.10214a. 